\title{
ANALISIS KEKERINGAN HIDROLOGI BERDASARKAN METODE PALMER DI DAERAH ALIRAN SUNGAI TIRTOMOYO KABUPATEN WONOGIRI
}

\author{
Rifka Annisa Arin ${ }^{1)}$, Rintis Hadiani ${ }^{2}$, Solichin ${ }^{3)}$ \\ 1) Mahasiswa Fakultas Teknik, Prodi Teknik Sipil, Universitas Sebelas Maret \\ 2) Pengajar Fakultas Teknik, Prodi Teknik Sipil, Universitas Sebelas Maret \\ 3) Pengajar Fakultas Teknik, Prodi Teknik Sipil, Universitas Sebelas Maret \\ Jl. Ir. Sutami 36A, Surakarta 57126; Telp. 0271-634524. \\ Email : rifkaannisa.ra@gmail.com
}

\begin{abstract}
Abstrak
DAS Tirtomoyo merupakan sub DAS Bengawan Solo Hulu 3 yang bermuara di Waduk Gajah Mungkur Wonogiri dan terletak di sebelah tenggara Kabupaten Wonogiri. Kabupaten Wonogiri memiliki curah hujan yang cukup rendah, sehingga mempengaruhi ketersediaan air di wilayah sekitarnya. Ketersediaan air yang rendah dapat menyebabkan terjadinya bencana kekeringan, salah satunya yaitu terjadi kekeringan di Daerah Aliran Sungai (DAS) Tirtomoyo.

Penelitian ini bertujuan untuk menganalisis kekeringan menggunakan indeks kekeringan metode Palmer dan mengetahui kriteria kering berdasarkan indeks kekeringan hidrologi serta memperoleh peta persebaran kekeringan menggunakan software ArcGIS. Perhitungan debit untuk indeks kekeringan hidrologi menggunakan rumus metode NRECA. Kemudian membuat grafik hubungan antara debit (Q) dengan indeks kekeringan Palmer.

Hasil yang didapat dari analisis menunjukan bahwa kekeringan paling parah terjadi pada bulan November periode II tahun 2010 dengan nilai indeks kekeringan Palmer sebesar X = -6,778; maka termasuk dalam kriteria amat sangat kering. Berdasarkan perhitungan debit yang berpotensi terjadinya bencana kekeringan yaitu pada bulan Juni hingga bulan Oktober tahun 2015 dengan ketersediaan air yang kecil. Hasil dari perhitungan debit dan indeks kekeringan Palmer dapat dibuat grafik hubungan diantara keduanya. Grafik tersebut menghasilkan nilai koefisien determinasi $\mathrm{R}^{2}$ sebesar 0,3593 dengan persamaan grafik $\mathrm{y}=2,5369 \mathrm{x}+$ 5,3702. Selanjutnya untuk memperoleh peta persebaran kekeringan digunakan software ArcGIS.

Kata kunci : DAS Tirtomoyo, Pemetaan, Kekeringan, NRECA, Metode Palmer.
\end{abstract}

\footnotetext{
Abstrack

Tirtomoyo watershed is a sub-section of Bengawan Solo Hulu 3 watershed, it drains into Waduk Gajah Mungkur Wonogiri and is located in the southeast of Wonogiri Regency. Wonogiri Regency has quite low rainfall, affecting the water availability in the surrounding region. The low availability of water can cause drought, one of which is a drought phenomenon in Tirtomoyo watershed.

This studying aims to analyzing drought using the index drought of Palmer's method and find out the dry criteria based on the bydrological drought index as well as to acquire drought distribution map using ArcGIS software. The flow calculation for the hydrological drought index uses the formula of NRECA method. Then the graph showing the correlation between the flow (Q) and the Palmer drought index was made.

The result of the analysis indicates that the most severe drought occurred in November period II in 2010 with the Palmer drought index of $X=-6,778$; consequently included in the driest criteria. Based on the flow calculation which has the potential to cause drought from June to October 2015 with low water availability. The result of the flow calculation and the Palmer drought index can be illustrated in a graph showing the relation between them. The graph shows a correlation value of $\mathrm{R}^{2}$ of 0,3593 with the graph equation of $y=2,5369 x+5,3702$. Furthermore, ArcGIS software is used to acquire the drought distribution map.

Keywords : Tirtomoyo watershed, Mapping, Drought, NRECA, Palmer's Method.
}

e-Jurnal MATRIKS TEKNIK SIPIL/Juni 2019/108 


\section{PENDAHULUAN}

Menurut International Glossary of Hidrology (WMO 1974), pengertian kekeringan adalah suatu keadaan tanpa hujan berkepanjangan atau masa kering di bawah normal yang cukup lama sehingga mengakibatkan keseimbangan hidrologi terganggu secara serius. Terjadinya kekeringan dapat disebabkan karena beberapa faktor, seperti minimnya sumber air, kurangnya daerah tangkapan air dan curah hujan yang kecil. Kekeringan sangat berpengaruh terhadap aktifitas manusia seperti pertanian, perikanan, peternakan dan aktifitas sehari-hari lainnya (Yesinta Dewi, 2016).

Indeks kekeringan hidrologi $(\mathrm{IKH})$ merupakan analisis kekeringan yang dihitung melalui pendekatan debit, dan dapat diprediksi berdasarkan interaksi iklim terkait dengan pola curah hujan atau debit yang pernah terjadi karena terdapat kecenderungan bahwa pola hujan atau debit dapat terjadi berulang dalam kurun waktu tertentu (Rr. Rintis Hadiani, 2009), maka pada penelitian ini akan menghubungkan indeks kekeringan berdasarkan metode Palmer dengan indeks kekeringan hidrologi dan akan digambarkan dalam bentuk grafik hubungan antara keduanya. Perhitungan analisis ketersediaan air dihitung menggunakan metode National Rural Electric Cooperative Assosiation (NRECA) dengan data hujan 15 harian.

Metode yang akan digunakan dalam penelitian ini adalah metode Palmer Drought Severity Index (PDSI) yang dilakukan pada Daerah Aliran Sungai Tirtomoyo Kabupaten Wonogiri, Jawa Tengah. Metode Palmer Drought Severity Index (PDSI) merupakan indeks kekeringan meteorologi yang didasarkan pada data curah hujan, suhu udara dan ketersediaan air dalam tanah. Analisis indeks kekeringan merupakan analisis yang menunjukkan tingkat kelas kekeringan karena tingkat kekeringan di suatu wilayah akan berbeda-beda.

Tujuan dari penelitian ini adalah untuk menganalisis indeks kekeringan pada DAS Tirtomoyo dan mengetahui sebaran kekeringan agar dapat mengestimasi adanya kekeringan. Hasil dari indeks kekeringan nantinya akan dibuat pemetaan persebaran kekeringan menggunakan software ArcGIS.

\section{TINJAUAN PUSTAKA}

Air merupakan sumber daya alam yang dapat diperbaharui melalui siklus hidrologi. Siklus hidrologi dapat dipengaruhi oleh iklim suatu wilayah. Perbedaan iklim di setiap wilayah merupakan salah satu penyebab terjadinya kekeringan. Kekeringan di suatu wilayah disebabkan karena terjadinya defisit air Julian Wabyu Purnomo Putro dke. 2016).

Kekeringan akan semakin parah jika terjadi peristiwa El Nino, karena pada peristiwa tersebut musim kemarau akan semakin panjang dan musim hujan menjadi pendek. Oleh karena itu perlu adanya analisis mengenai kekeringan agar dapat mengestimasi adanya bencana kekeringan.

Identifikasi potensi kekeringan dapat dipermudah dengan bantuan software Arcgis. Sistem Informasi Geografis (GIS) merupakan system informasi yang digunakan untuk memasukkan, menyimpan, memanggil kembali, mengolah, menganalisis dan menghasilkan data bereferensi geografis atau geospital, untuk mendukung pengambilan keputusan dalam perencanaan dan pengelolaan penggunaan lahan, sumber daya alam, lingkungan, transportasi, fasilitas kota, dan pelayanan umum lainnya (Murai, 1999).

\section{DASAR TEORI}

\section{Karakteristik Hujan}

Data hujan yang diperoleh sebelum diolah dilakukan uji kepanggahan, setelah itu dilakukan pengolahan data hujan wilayah menggunakan metode Thiessen.

Hujan rerata daerah aliran sungai dapat dhitung menggunakan persamaan (1) :

$\frac{P_{x}}{N_{x}}=\frac{1}{n}\left(\frac{P_{1}}{N_{1}}+\frac{P_{2}}{N_{2}}+\frac{P_{3}}{N_{3}}+\cdots+\frac{P_{n}}{N_{n}}\right)$ 


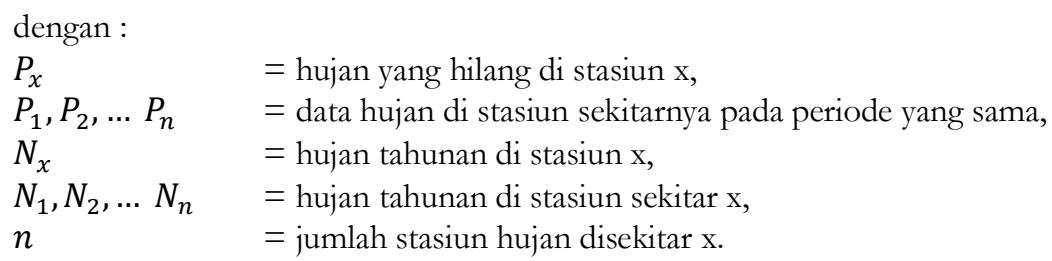

\section{Evapotransprasi}

Evapotranspirasi merupakan banyaknya air yang digunakan untuk proses pertumbuhan tanaman (transpirasi) dan evaporasi tanah (SNI 7745 : 2012). Evapotranspirasi dihitung berdasarkan metode Thornthwaite - Matter dengan input data klimatologi berupa temperature rata-rata.

Perhitungan evapotranspirasi potensial dapat dihitung menggunakan persamaan (2) - (4) :

$P E T=16,2\left[\left(10 T_{a}\right) / I\right]^{a}$

dengan :

PET = evapotranspirasi potensial $(\mathrm{mm})$,

$\mathrm{T}_{\mathrm{a}} \quad=$ suhu rata-rata bulanan $\left({ }^{\circ} \mathrm{C}\right)$.

$I=\sum_{i=1}^{12}\left[\left(T_{a i} / 5\right)\right]^{1,5}$

dengan :

$\mathrm{a}=0,49+0,0179 \mathrm{I}-0,0000771 \mathrm{I}^{2}+0,000000675 \mathrm{I}^{3}$

\section{Ketersediaan Air}

Perhitungan ketersediaan air dihitung menggunakan metode NRECA. Perhitungan NRECA sesuai untuk daerah cekungan yang setelah hujan berhenti masih ada aliran air sungai selama beberapa hari. Kondisi ini terjadi bila tangkapan hujan cukup luas.

Data dan asumsi yang diperlukan dalam perhitungan metode NRECA yaitu sebagai berikut:

a. Debit aliran rerata,

b. Aliran langsung,

c. Aliran air tanah,

d. Kelebihan kelengasan,

e. Tampungan kelengasan,

f. Parameter yang menggambarkan karakteristik tanah permukaan,

g. Parameter yang menggambarkan karakteristik tanah bagian dalam,

h. Keseimbangan air,

i. Rasio kelebihan kelengasan,

j. Curah hujan,

k. Evapotranspirasi actual,

1. Evapotranspirasi potensial (Eto),

m. Tampungan kelengasan tanah,

n. Tampungan kelengasan awal,

o. Curah hujan tahunan.

\section{Koefisien Limpasan (C)}

Limpasan adalah intensitas hujan yang melebihi kapasitas infiltrasi, setelah laju infiltrasi terpenuhi, maka air akan mengisi cekungan-cekungan pada permukaan tanah. Koefisien Limpasan merupakan bilangan perbandingan antara laju debit puncak dengan intensitas hujan. Koefisien limpasan dipengaruhi oleh 
berbagai faktor seperti laju infiltrasi, keadaan tata guna lahan atau tutupan lahan, intensitas hujan, permeabilitas dan kemampuan tanah menahan air (Asdak, 2004)

\section{Palmer Drought Saverity Index (PDSI)}

Metode Palmer Drought Severity Index (PDSI) merupakan indeks kekeringan meteorologi yang didasarkan pada data curah hujan, suhu udara dan ketersediaan air dalam tanah. Analisis indeks kekeringan dengan menggunakan metode Palmer meliputi perhitungan parameter utama dan perhitungan parameter iklim.

Analisis parameter utama

a. P, hujan kumulatif bulanan wilayah efektif,

b. PET, evapotranspirasi potensial metode Thornthwaite,

c. $\Delta$ Sa, perubahan lengas tanah lapisan atas,

d. $\Delta \mathrm{Sb}$, perubahan lengas tanah lapisan bawah,

e. Sa, lengas tanah lapisan atas,

f. Sb, lengas tanah lapisan bawah,

g. S, lengas tanah (available water content),

h. PR, jumlah air yang dapat diserap oleh tanah,

i. R, pengisian lengas ke dalam tanah,

j. PLa, kehilangan kelembaban tanah potensial lapisan atas,

k. PLb, kehilangan kelembaban tanah potensial lapisan bawah,

1. PL, kehilangan kelembaban tanah potensial kedua lapisan,

m. L, kehilangan kelembaban tanah,

n. ET, evapotranspirasi,

o. PRO, aliran permukaan potensial,

p. RO, Aliran permukaan.

Analisis parameter iklim (Palmer, 1965)

Menentukan nilai koefisien untuk mendapatkan nilai CAFEC (Climatically Appropriate for Existing Conditons)

$\propto=\overline{E T} / \overline{P E T}$

$\beta=\bar{R} / \overline{P R}$

$\gamma=\overline{R O} / \overline{P R O}=\overline{R O} / \overline{S^{\prime}}$

$\delta=\bar{L} / \overline{P L}$

$\kappa=(\overline{P E T}+\bar{R}) /(\bar{P}+\bar{L})$

dengan: $\alpha=$ koefisien evapotranspirasi; $\beta=$ koefisien pengisian lengas ke dalam tanah; $\gamma=$ koefisien limpasan; $\delta=$ koefisien kehilangan air; $\kappa=$ pendekatan terhadap pembobot iklim; $\overline{E T}=$ rata-rata evapotranspirasi; $\overline{P E T}=$ rata-rata evapotranspirasi potensial; $\bar{R}=$ rata-rata pengisian lengas ke dalam tanah; $\overline{P R}=$ rata-rata pengisian lengas ke dalam tanah potensial; $\overline{R O}=$ rata-rata aliran permukaan; $\overline{P R O}=$ rata-rata aliran permukaan potensial; $\bar{S}^{\prime}=$ rata-rata kelembaban tanah; $\bar{L}=$ rata-rata kehilangan kelembaban tanah; $\overline{P L}=$ rata-rata kehilangan kelembaban tanah potensial; $\bar{P}=$ rata-rata presipitasi.

Nilai $C A F E C$

$\widehat{E T} \quad=\alpha \mathrm{PET}$

$\hat{R} \quad=\beta P R$

$\widehat{R O} \quad=\gamma \mathrm{PRO}$

$\hat{L} \quad=\delta P L$

$\hat{P} \quad=\widehat{E T}+\widehat{R}+\widehat{R O}-\hat{L}$

dengan $: \widehat{E T}=$ nilai evapotranspirasi $C A F E C ; \widehat{R}=$ nilai pengisian lengas ke dalam tanah CAFEC; $\widehat{R O}=$ nilai aliran permukaan CAFEC; $\hat{L}=$ nilai kehilangan lengas tanah CAFEC; $\hat{P}=$ nilai presipitasi CAFEC; PET= 
evapotranspirasi potensial; $\mathrm{PR}=$ pengisian lengas ke dalam tanah potensial; $\mathrm{PRO}=$ aliran permukaan potensial; $\mathrm{PL}=$ kehilangan lengas tanah potensial.

Periode kelebihan dan kekurangan hujan

$d=P-\hat{P}$

dengan $: \mathrm{d}=$ periode kelebihan dan kekurangan hujan; $\mathrm{P}=$ curah hujan; $\hat{P}=$ nilai presipitasi CAFEC.

$(\bar{D})=$ rata-rata nilai mutlak dari $\mathrm{d}$

Pendekatan kedua terhadap nilai faktor K (K')

$K^{\prime}=1,5 \log _{10}\left[\left(\frac{P E T+R+R O}{P+L}+2,80 / \frac{25,6}{\bar{D}}\right)\right]+0,5$

$D K^{\prime}=\bar{D} x K^{\prime}$

dengan : $K^{\prime}=$ pendekatan kedua terhadap nilai faktor $\mathrm{K}$; PET= evapotranspirasi potensial $(\mathrm{mm})$; $\mathrm{R}=$ nilai pengisian lengas ke dalam tanah $\mathrm{CAFEC}$; $\mathrm{RO}=$ nilai aliran permukaan $\mathrm{CAFEC} ; \mathrm{P}=$ curah hujan; $\mathrm{L}=$ nilai kehilangan lengas tanah CAFEC; $\bar{D}=$ rata-rata nilai mutlak dari d.

Karakter iklim sebagai factor pembobot (K)

$K=\frac{\bar{D} \times K^{\prime}}{\sum_{1}^{12} \bar{D} \times K^{\prime}}$

dengan : $\mathrm{K}=$ karakter iklim sebagai factor pembobot; $\bar{D}=$ rata-rata nilai mutlak dari d; $K^{\prime}=$ pendekatan kedua terhadap nilai faktor $\mathrm{K}$.

Penduga nilai $Z$

$\mathrm{z}=\mathrm{d} \mathrm{x} x$

dengan $: z=$ penduga nilai $Z ; d=$ periode kelebihan dan kekurangan hujan; $x=$ pendekatan terhadap pembobot iklim.

Indeks penimpangan atau anomaly lengas (Z)

$Z=\mathrm{d} \times \mathrm{K}$

dengan : $\mathrm{Z}=$ indeks penimpangan atau anomaly lengas; $\mathrm{d}=$ periode kelebihan dan kekurangan hujan; $\mathrm{K}=$ karakter iklim sebagai factor pembobot.

Indeks kekeringan $(\mathrm{X})$

$X=(Z / 3)_{i-1}+\Delta X$

dengan:

$\Delta X=(Z / 3)_{i}-0,103(Z / 3)_{i-1}$

dengan :

$\mathrm{X}=$ indeks kekeringan,

$\mathrm{Z} \quad=$ indeks penimpangan atau anomaly lengas. 


\section{Kriteria Kering}

Tabel 1 Kriteria Kering Metode Palmer

\begin{tabular}{|rll|l|}
\hline \multicolumn{3}{|c|}{ X } & \multicolumn{1}{c|}{ Klasifikasi } \\
\hline & $\geq$ & 0.50 & Basah \\
\hline 0.49 & - & $(-0.49)$ & Normal \\
\hline$(-0.50)$ & - & $(-2.99)$ & Kering \\
\hline$(-3.00)$ & - & $(-3.99)$ & Sangat kering \\
\hline & $\leq$ & $(-4.00)$ & Amat sangat kering \\
\hline
\end{tabular}

(Sumber : Palmer, 1965)

\section{METODE PENELITIAN}

\section{Data}

Data yang dibutuhkan dalam analisis perhitungan penelitian yaitu data curah hujan harian beserta koordinat stasiun hujan DAS Tirtomoyo (Watugede, Tirtomoyo, Balong) kurun waktu 10 Tahun (2008 2017), peta rupa bumi skala 1 : 25000, data klimatologi dengan rentang waktu 10 Tahun (2008 - 2017).

\section{Lokasi Penelitian}

Penelitian dilakukan di Daerah Aliran Sungai (DAS) Tirtomoyo yang terletak pada 756'56,94" -

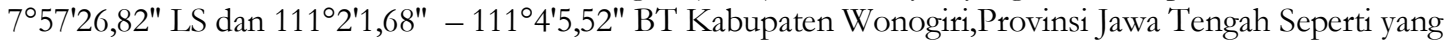
dapat dilihat pada Gambar.1.

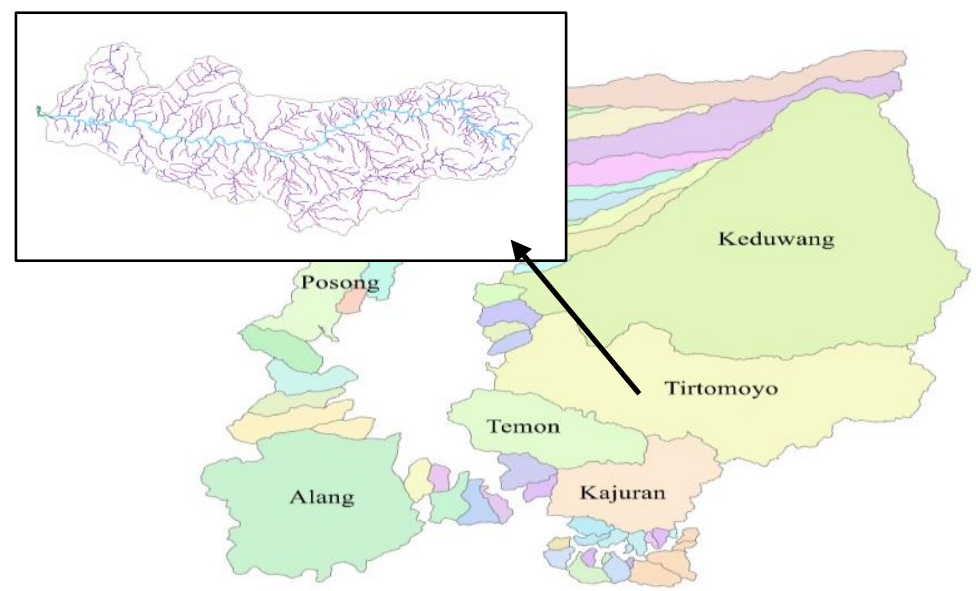

Gambar 1 Lokasi Penelitian

\section{Tahapan Penyelesaian Studi}

a. Pengumpulan data sekunder

Pengisian data yang hilang menggunakan metode Reciprocal.

b. Pengujian data

Data yang diperoleh diuji menggunakan konsistensinya menggunakan metode kurva masa ganda.

c. Perhitungan evapotranspirasi

Evapotranspirasi dihitung menggunakan metode Thornthwaite, dengan input berupa suhu rata-rata 15 harian.

d. Perhitungan ketersediaan air

Perhitungan ketersediaan air dihitung menggunakan metode NRECA.

e. Perhitungan indeks kekeringan 
Indeks kekeringan pada penelitian ini menggunakan metode Palmer Drought Severity Index (PDSI).

Metode Palmer merupakan indeks kekeringan meteorologi yang didasarkan pada data curah hujan, suhu udara dan ketersediaan air dalam tanah.

f. Pemetaan indeks kekeringan

g. Grafik korelasi antara debit dan indeks

\section{HASIL DAN PEMBAHASAN}

\section{Pengujian Konsistensi Data}

Berdasarkan hasil uji konsistensi data hujan menggunakan kurva massa ganda pada Daerah Aliran Sungai (DAS) Tirtomoyo tidak ditemukan adanya data yang menyimpang sehingga data hujan dianggap konsisten dan dapat digunakan untuk perhitungan indeks kekeringan menggunakan metode Palmer.

\section{Analisis Hujan Titik menjadi Hujan Wilayah}

Untuk menentukan hujan wilayah di Daerah Aliran Sungai (DAS) Tirtomoyo menggunakan metode Polygon Thiessen dengan tinjauan 3 stasiun hujan dan luasan DAS Tirtomoyo sebesar 202,5591 km². Setelah dianalisa didapatkan koefisien thiessen dari masing-masing stasiun yaitu Pos Watugede dengan luas $84,5404 \mathrm{~km}^{2}$ maka koefisien thiessen sebesar 0,4174; Pos Tirtomoyo dengan luas 40,9875 $\mathrm{km}^{2}$ maka koefisien thiessen sebesar 0,2023; Pos Balong dengan luas 77,0311 $\mathrm{km}^{2}$ maka koefisien thiessen sebesar 0,3803 .

\section{Evapotranspirasi Potensial}

Evapotranspirasi dihitung menggunakan metode Tornthwaite Matter. Besar nilai evapotranspirasi potensial pada bulan Januari periode I tahun 2008 yaitu sebesar 135,2600 mm.

\section{Perhitungan Ketersediaan Air}

Perhitungan ketersediaan air dihitung berdasarkan metode NRECA dengan input berupa debit aliran rerata, aliran langsung, aliran air tanah, kelebihan kelengasan, tampungan kelengasan, parameter yang menggambarkan karakteristik tanah permukaan, parameter yang menggambarkan karakteristik tanah bagian dalam, keseimbangan air, rasio kelebihan kelengasan, curah hujan, evapotranspirasi actual, evapotranspirasi potensial (Eto), tampungan kelengasan tanah, tampungan kelengasan awal, curah hujan tahunan.

\section{Indeks Kekeringan}

Indeks kekeringan diperoleh berdasarkan analisis perhitungan menggunakan metode Moisture Adequacy Index merupakan perbandingan antara evapotranspirasi aktual dengan evapotranspirasi potensial.

\section{Klasifikasi Kekeringan}

Indeks kekeringan yang telah dihitung diklasifikasikan kekeringannya berdasarkan CAZRI (Central Arid Zone Research Institute) dalam Tabel 1.

\section{Grafik Korelasi Debit dan Indeks}

Grafik korelasi antara debit ketersediaan air dan indeks kekeringan dibuat bertujuan untuk mengetahui trend bencana kekeringan yang terjadi di Daerah Aliran Sungai (DAS) Tirtomoyo. Grafik hubungan antara debit ketersediaan air dan indeks kekeringan ditampilkan pada Gambar 2. 


\section{GRAFIK HUBUNGAN DEBIT DENGAN INDEKS KEKERINGAN PALMER}

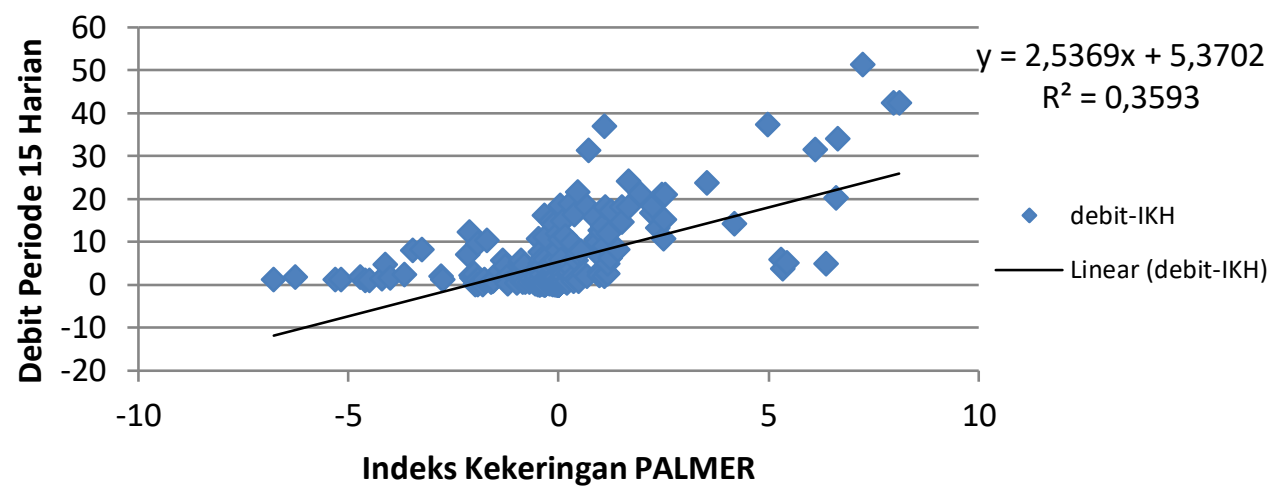

Gambar 2 Grafik Korelasi antara Debit Ketersediaan Air dan Indeks

Dari grafik diatas maka trend bencana kekeringan yang akan datang dapat diperkirakan menggunakan persamaan $\mathrm{y}=2,5369 \mathrm{x}+5,3702$ dengan $\mathrm{y}$ debit dan $\mathrm{x}$ adalah indeks.

\section{Pemetaan Kekeringan}

Hasil analisa perhitungan indeks kekeringn berdasarkan metode Palmer selanjutnya diklasifikasikan menurut indeks kekeringan Palmer setelah itu dipetakan menggunakan software ArcGIS. Warna dalam pemetaan kekeringan berubah dari merah tua ke hijau, kering ke basah. Warna merah yang artinya "amat sangat kering", warna coklat yang artinya "sangat kering", warna kuning yang artinya "kering", warna hijau muda yang artinya "normal", dan warna hijau terang yang artinya "basah" (SNI 6728.1 : 2015). Pemetaan kekeringan dapat dilihat pada Gambar 3 - Gambar 12.

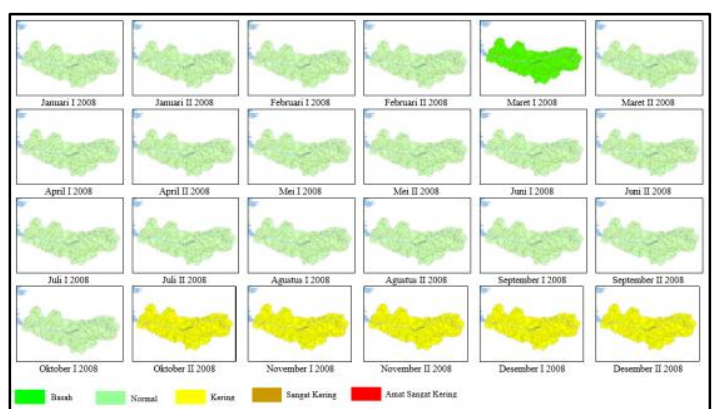

Gambar 3 Pemetaan Tahun 2008

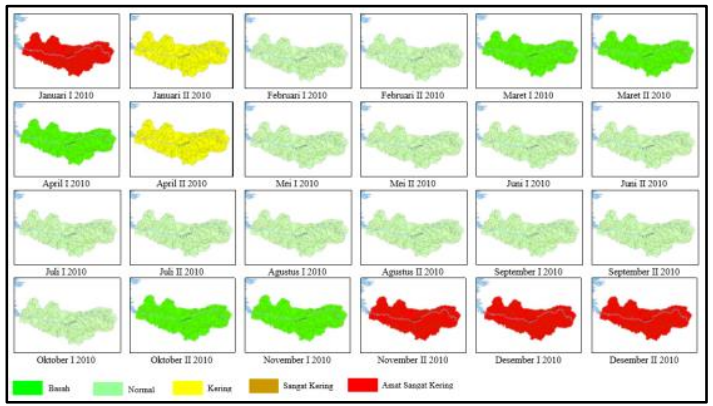

Gambar 5 Pemetaan Tahun 2010

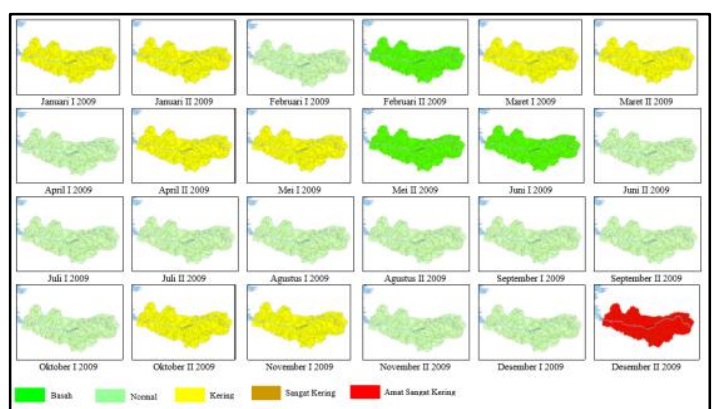

Gambar 4 Pemetaan Tahun 2009

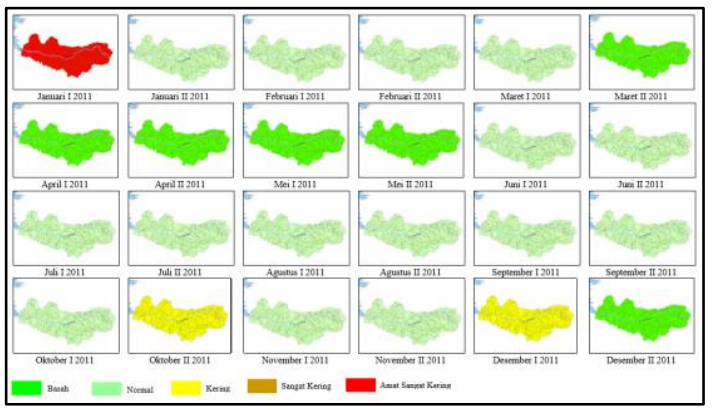

Gambar 6 Pemetaan Tahun 2011 


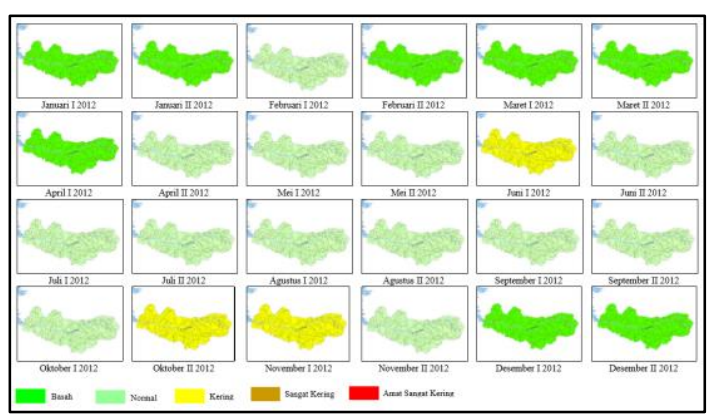

Gambar 7 Pemetaan Tahun 2012

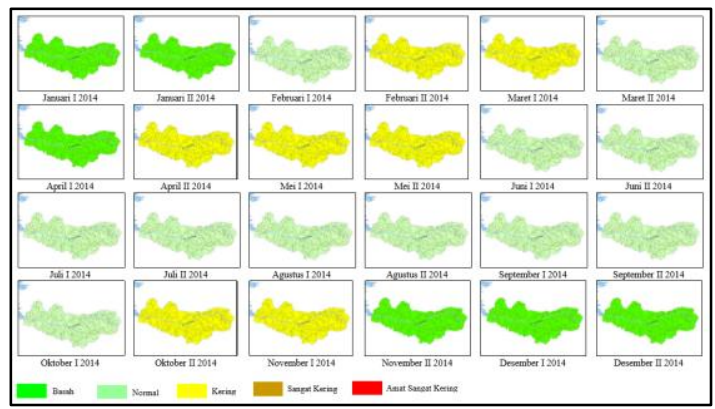

Gambar 9 Pemetaan Tahun 2014

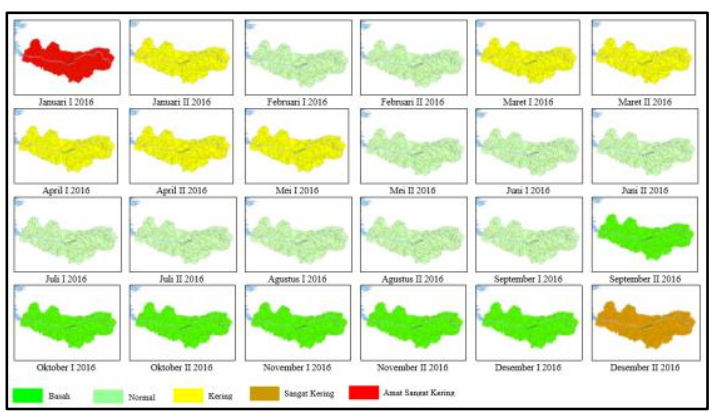

Gambar 11 Pemetaan Tahun 2016

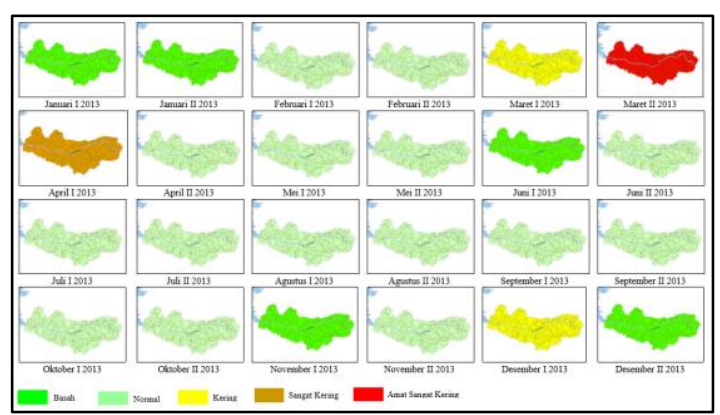

Gambar 8 Pemetaan Tahun 2013

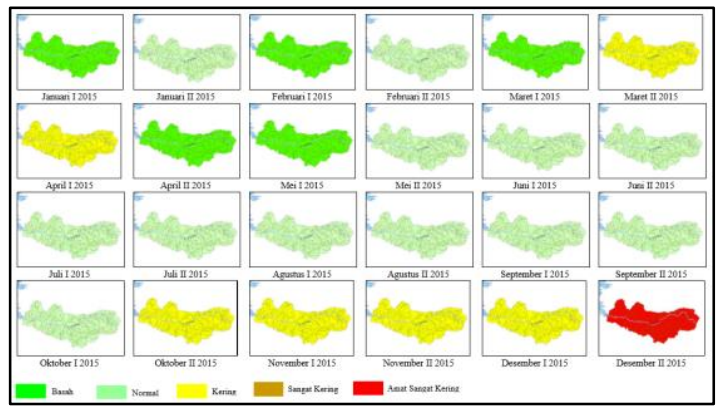

Gambar 10 Pemetaan Tahun 2015

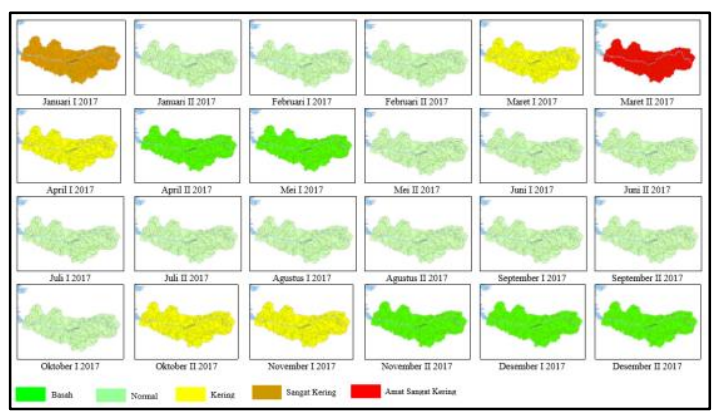

Gambar 12 Pemetaan Tahun 2017

\section{KESIMPULAN}

Berdasarkan hasil perhitungan yang telah dilakukan maka dapat diambil kesimpulan sebagai berikut :

1. Debit 15 harian yang dihasilkan menggunakan metode NRECA pada Daerah Aliran Sungai (DAS) Tirtomoyo menghasilkan debit yang bervariasi dengan rentang antara $0,0000156 \mathrm{~m}^{3} /$ detik sampai $51,4125 \mathrm{~m}^{3} /$ detik. Debit minimum terjadi pada bulan Oktober periode II tahun 2015, sedangkan debit maksimum terjadi pada bulan November periode II tahun 2017. Tidak adanya ketersediaan air terjadi rata-rata pada bulan Juni sampai bulan Oktober.

2. Berdasarkan indeks kekeringan menggunakan metode Palmer pada Daerah Aliran Sungai (DAS) Tirtomoyo menghasilkan nilai indeks dengan rentang -6,778 sampai 8,105. Kering terparah sebesar X $=-6,778$ dengan klasifikasi amat sangat kering yang terjadi pada bulan November periode II tahun 2010. Bulan terbasah sebesar X = 8,105 terjadi pada bulan Oktober periode II tahun 2010.

3. Grafik yang terbentuk merupakan hubungan antara debit ketersediaan air (sumbu y) dan indeks kekeringan Palmer (sumbu x) yang menghasilkan koefisien determinasi $\mathrm{R}^{2}$ sebesar 0,3596 dengan persamaan grafik $y=2,5443 x+5,8041$ dan didapatkan keandalan hanya sebesar $60 \%$, dikarenakan 
bentuk data yang sedikit berbeda karena faktor input data antara perhitungan debit dengan perhitungan indeks kekeringan Palmer.

4. Pemetaan kekeringan pada Daerah Aliran Sungai (DAS) Tirtomoyo dihasilkan dari nilai indeks kering Palmer berdasarkan data 15 harian dengan rentang warna merah (amat sangat kering) sampai hijau (basah). Warna yang dihasilkan digunakan untuk mengetahui persebaran kekeringan. Pemetaan dapat digunakan sebagai mitigasi bencana kekeringan di Daerah Aliran Sungai (DAS) Tirtomoyo.

\section{DAFTAR PUSTAKA}

Chay Asdak, 2004. Hidrologi dan Pengelolaan Daerah Aliran Sungai. Universitas Gadjah Mada Press. Yogyakarta.

Julian Wahyu Purnomo Putro, Rintis Hadiani dan Suyanto, 2016. Implementasi Metode Palmer untuk. Analisis Kekeringan pada Daerah Aliran Sungai Temon Kabupaten Wonogiri. Universitas Sebalas Maret. Surakarta.

Murai, 1999. GIS Work Book. Institute of Industrial Science. University of Tokyo. 7-22-1 Roppongi. Minatoku. Tokyo.

Setiono, Rintis Hadiani. 2009. Analysis Pf Rainfall-Runoff Neuron Input Model With Artificial Neural Network For Simulation For Availability Of Discharge At Bah Balon Watershed. Sebelas Maret University. Surakarta.

SNI 6728.1 : 2015. Badan Standardisasi Nasional. Neraca Air

SNI 7745 : 2012. Badan Standardisasi Nasional. Tata Cara Perhitungan Evapotranspirasi Tanaman Acuan dengan Metode Penman - Monteith.

Wayne C Palmer, 1965. Meteorological Drought. Research Paper, No 45. Washington DC.

Word Meteorogical Organization (WMO), 1974. International Glossary of Hidrology.

Yesinta Dewi, 2016. Makalah Kekeringa dan Indeks Kekeringan. Universitas Pembangunan Nasional "Veteran". Yogyakarta. 